\title{
GEOECOLOGIA DA PAISAGEM X LEGISLAÇÃO AMBIENTAL: UMA ANÁLISE DA DISTRIBUIÇÃO ESPACIAL DAS RESTRIÇÕES AO USO DA TERRA FRENTE À PROBLEMÁTICA EROSIVA NA ALTA BACIA DO RIBEIRÃO AREIA DOURADA, MARABÁ PAULISTA (SP)
}

\section{Geoecology of the landscape $X$ environmental legislation: an analysis of the spatial distribution of the land use restrictions and ther relation with erosion issues in the upper basin of the river Areia Dourada, Marabá Paulista (SP)}

Felipe Augusto Scudeller Zanatta felipeasz@hotmail.com

Universidade Estadual Paulista Júlio de Mesquita - UNESP, Rio Claro, São Paulo, Brasil

Cenira Maria Lupinacci cenira@rc.unesp.br Universidade Estadual Paulista Júlio de Mesquita - UNESP, Rio Claro, São Paulo, Brasil

Marcos Norberto Boin boinmar@hotmail.com Universidade Federal da Grande Dourados, Dourados, Mato Grosso do Sul, Brasil

RESUMO: $\quad$ A promulgação do atual Código Florestal (Lei 12.651/12) gerou preocupações quanto à preservação e à proteção dos recursos naturais nos diferentes Biomas do Brasil, muito devido ao seu caráter genérico e a tolerância aos usos abusivos. Frente a essa questão, neste artigo é apresentado um estudo aplicado e comparativo das restrições ao uso nas propriedades privadas de acordo o atual Código Florestal, e com o zoneamento ambiental, elaborado a partir da proposta da geoecologia da paisagem, aplicados na alta bacia do ribeirão Areia Dourada, Marabá Paulista (SP). Assim, tem-se como objetivo avaliar as diferenças espaciais na restrição ao uso da terra identificadas em consonância com a Lei 12.651/12 e com o estudo conduzido a partir da metodologia da Geoecologia, que se caracteriza por integrar os diversos elementos que compõem a paisagem natural. Ademais, foram acrescidas à análise as feições erosivas lineares, no intuito de comparar a fragilidade natural da bacia com as consequências de usos inadvertidos. Como resultado, o atual Código Florestal contempla a preservação de apenas 6,28\% (290,55 ha) da área estudada, o que tende a agravar a problemática erosiva, enquanto o zoneamento com base na Geoecologia aponta para a necessidade de preservar, pelo menos, 51,66\% (2.388,28 ha). Esses terrenos ainda incidem diretamente nas áreas com erosões em ravinas e voçorocas, indicando de forma eficiente a fragilidade natural da bacia.

Palavras-chave: Lei 12.651/12; Tolerância aos usos abusivos; Geoecologia da Paisagem; Fragilidade natural.

DOI: http://dx.doi.org/10.1590/1982-451320160102 
ABSTRACT: The enactment of the current Forest Code (Law 12.651/12) raised concerns regarding the preservation and protection of natural resources in different biomes of Brazil, due to its very general nature and tolerance to abusive uses. Facing to this question, this article is presented applied and comparative study of the use restrictions on private properties as the current Forest Code and the environmental zoning drawn from the proposal Geoecology of the landscape, applied in the high basin of Areia Dourada, Marabá Paulista (SP). Thus, we intend to evaluate the spatial differences in restricting land use identified in accordance with Law 12.651/12 and to a study conducted using the methodology of Geoecology, which is characterized by integrating the various elements that make up the natural landscape. Still, were added to the analysis linear erosional features in order to compare the fragile nature of the basin with the consequences of inadvertent use. As a result, the current Forest Code contemplates only 6,28\% (290,55 ha) of the watershed area, which tends to aggravate erosive problematic as the methodology of Geoecology points to the need for preservation of $51,66 \%(2.388,28 \mathrm{ha})$. This land is directly affect by the areas of erosion in ravines and gullies, indicating efficiently the natural fragility of the basin.

Keywords: Law 12.651 / 12; Tolerance for abusive purposes; Landscape Geoecology; Natural fragility.

\section{INTRODUÇÃO}

\section{Do Código florestal brasileiro à Geoecologia da Paisagem}

As discussões sobre a necessidade de preservação eproteçãoambientalnoâmbitolegislativo brasileiro são recentes, quando comparadas ao processo de ocupação e transformação dos ambientes naturais em território nacional. Os avanços no conhecimento sobre a natureza, em sua dinâmica, e as preocupações com as questões ambientais, sobretudo pela finitude dos recursos e da função protetora da vegetação nativa nos ambientes, foram modificando as leis, que incorporaram tais debates e ampliaram a eficiência teórica na preservação ambiental. Entretanto, atualmente, com a expansão da fronteira agrícola no país e o domínio ruralista na política, a legislação ambiental, principalmente o Código Florestal brasileiro, sofreu retrocesso significativo.

O primeiro Código Florestal brasileiro surge na década de 1930 , determinando que $25 \%$ das propriedades rurais deveriam ser ocupadas por vegetação nativa, mas sem definir em quais áreas essa proteção deveria se situar, ficando, assim, a critério do proprietário a escolha. Como na época a lenha era fonte de energia, abastecendo as casas e locomotivas, a necessidade da cobertura vegetal nativa estava atrelada à reserva de madeira; desta forma, a preocupação não tinha um caráter de preservação ou proteção ambiental e sim de reserva madeireira para consumo.

$\mathrm{Na}$ década de 1960, tem início a edição de normas com maiores referências às questões ambientais propriamente ditas. Entre os textos legislativos mais importantes surge o Código Florestal de 1965, trazendo em seu bojo discussões mais avançadas quanto à função das florestas e das demais formas de vegetação nativa. O Código de 1965, isto é, a Lei 4.771, estabelece em seu Art. $1^{\circ}$ que:

As florestas existentes em território nacional e as demais formas de vegetação, reconhecidas de utilidade às terras que revestem, são bens de interesse comum a todos os habitantes do País, exercendo-se os direitos de propriedade, com as limitações que a legislação em geral e especialmente esta Lei estabelecem. (BRASIL, 1965 Art. 1º)

Ao definir que as florestas possuem utilidade "às terras que revestem" e que "são bens de interesse comum a todos os habitantes", a lei se mostra extremamente avançada em relação às pautas ambientais, já que incorpora a função ecológica da vegetação nativa na ciclagem de nutrientes e formação dos solos, como abrigo de biodiversidades e reguladora do ciclo hidrológico. Por isso, estabelece que, mesmo dentro das propriedades rurais, existe a questão social de preservar e proteger os recursos 
naturais por meio de duas distintas áreas: as Áreas de Preservação Permanente (APP's) e a Reserva Legal (RL).

A primeira, as APP's, estão locadas em setores específicos, onde a preservação da área, ou seja, a manutenção da integridade e perenidade da vegetação nativa tem como "função ambiental de preservar os recursos hídricos, a paisagem, a estabilidade geológica, a biodiversidade, o fluxo gênio de fauna e flora, proteger o solo e assegurar o bem-estar das populações humanas" (BRASIL, $1965 \S 1^{\circ}$, Inciso II). Esses terrenos, de acordo com Art. $2^{\circ}$, estão locados: nas margens de rios ou qualquer curso d'água em seu nível mais alto (a); ao redor das lagoas, lagos ou reservatórios naturais ou artificiais (b); nas nascentes, ainda que intermitentes, em qualquer que seja sua situação topográfica (c); topo de morros, montes, montanhas e serras (d); nas encostas com declive superior a $45^{\circ}(\mathrm{e})$; nas restingas (f); nas bordas de tabuleiros ou chapadas (g) e; em altitude superior a $1.800 \mathrm{~m}(\mathrm{~h})$. Ainda, de acordo com o Art. $3^{\circ}$, é possível ser declarada APP quando o Poder Público considerar a necessidade de preservação de uma determinada área, como, por exemplo, aquela essencial para atenuar a erosão das terras.

Já a Reserva Legal (RL) tem como função a proteção de uma parte da propriedade, onde o uso é possível desde que de forma sustentável, que permita a reabilitação dos processos ecológicos e a conservação da biodiversidade, sendo mantida como abrigo e proteção de fauna e flora nativas. Essa área não tem localização definida em lei, estando a critério do proprietário e do órgão ambiental em que parte da propriedade exercer a proteção. No entanto, sua porcentagem se distingue de acordo com a localização da propriedade em território nacional, sendo: $80 \%$ na Amazônia Legal; 35\% em área de cerrado na Amazônia Legal; e 20\% nas demais regiões do país.

Embora a Lei 4.771 de 1965 seja considerada avançada quanto ao caráter holístico empregado na preservação e proteção do ambiente mediante a vegetação nativa, em relação a um país de dimensões continentais, onde existem e coexistem distintos ecossistemas, climas e formas de relevo, o caráter genérico embutido nas APP's torna sua eficiência relativa, contemplando a preservação em determinados domínios morfoclimáticos, como também contribuindo para a degradação ambiental em outros.

Estudos como da Connecticut River Joint Commissions (CRJC, 1998) apontam que para suprir todas as funções estabelecidas para as APP's de canais fluviais são necessários no mínimo 180 metros (90 em cada margem do rio) de área preservada. Isso ocorre apenas em determinadas situações, sendo assim, o Código também é ineficiente quando a faixa de proteção é inferior à referida medida.

Não bastando as limitações da Lei 4.771/65, as alterações recentes no novo Código Florestal, mediante a promulgação da Lei 12.651/12, diminuem significativamente as restrições ao uso nas propriedades privadas, reduzindo as áreas com função de proteção e preservação do meio. A nova lei não modifica a localização das APP's de canais fluviais, no entanto, diminui a faixa de proteção devido a três circunstâncias: considera o leito regular, ou vazante, e não mais o leito maior sazonal dos rios; exclui a necessidade da APP em reservatórios artificiais com área menor que 1 ha e; permite o uso de parte da APP quando considerada área rural consolidada, reduzindo a área a ser preservada de acordo com a dimensão da propriedade, medida a partir do Módulo Fiscal, ou seja, quanto menor a propriedade, menor a faixa de APP, chegando, em algumas circunstâncias, a 5 metros de área a ser preservada. Sobre a questão, Ab'Sáber (2010) observa que:

Imagine-se que para o Rio Amazonas, a exigência protetora fosse apenas sete metros, enquanto para a grande maioria dos ribeirões e córregos também fosse aplicada a mesma exigência. Trata-se de desconhecimento entristecedor sobre a ordem de grandeza das redes hidrográficas do território intertropical brasileiro. Na linguagem amazônica tradicional, o próprio povo já reconheceu fatos referentes à tipologia dos rios regionais. Para eles, ali existem, em ordem crescente: igarapés, riozinhos, rios e parás. Uma última divisão lógica e pragmática, que é aceita por todos os que conhecem a realidade da rede fluvial amazônica (AB'SÁBER, 2010 p.332). 
Ao aplicar e comparar os Códigos de 1965 e 2012 na alta bacia do ribeirão Areia Dourada, Zanatta et al. (2014) verificaram que o atual Código Florestal, em relação ao 1965, promoveu uma redução de aproximadamente $70 \%$ do total das APP's de canais fluviais, o que não apenas diminui a eficiência na preservação dos recursos naturais, como também agrava a problemática erosiva significativa da área. Em relação à análise dos dois Códigos, os autores concluem que:

Tanto técnica, quanto cientificamente, as funções das faixas de proteção dos corpos d'água não são atendidas nos Códigos Florestais de 1965 e 2012. A evolução da legislação ambiental, que ao longo do último século teve inúmeros avanços, à medida que a pressão sobre os recursos naturais se tornava flagrante aos olhos da sociedade, sofreu um grande retrocesso com o novo Código Florestal. (ZANATTA et al., 2014, p. 2013).

Quanto à Reserva Legal, o Novo Código determina no Art.15, que "será admitido o cômputo das Áreas de Preservação Permanente no cálculo do percentual da Reserva Legal de imóvel”. Dessa forma, em determinadas propriedades, dependendo da porcentagem de área que a APP ocupa, a RL pode chegar a $0 \%$. Nessa situação, a diferença conceitual de proteção e preservação é insignificante. O Art. 66, $\S 6^{\circ}$, Inciso II, possibilita que a compensação da RL seja feita em outra área, desde que no mesmo bioma, ou seja, distante de onde a vegetação foi suprimida. A lei 12.651 de 2012 ainda diminuiu para 50\% a RL na Amazônia Legal florestada quando "o Estado tiver Zoneamento Ecológico-Econômico aprovado e mais de $65 \%$ do seu território ocupado por Unidade de Conservação da natureza de domínio público, devidamente regularizadas, e por terras indígenas homologadas" (BRASIL, 2012, Art. 12, Inciso I, § 5) e, nos demais biomas do país, que a área da RL pode ser reduzida em $50 \%$ quando o Município em questão "tiver mais de $50 \%$ da área ocupada por Unidades de Conservação da natureza de domínio público ou por terras indígenas homologadas" (BRASIL, 2012, Art. 12, Inciso II, $\S 4^{\circ}$ ).
A presença da vegetação nativa nas propriedades rurais tem função vital para as plantações de diversas espécies alimentícias, pois abrigam insetos, como as abelhas e besouros, que promovem a polinização dos cultivos, resultando em frutos de melhor qualidade, peso e sementes em maior quantidade. De acordo com Aizen et al. (2009 apud IMPERATRIZ-FONSECA; NUNES-SILVA, 2010, p.61), "no caso das culturas dependentes da polinização, na ausência de polinizadores seria necessário plantar uma área seis vezes maior para obter a mesma produtividade", complementando que "essa situação pode acelerar o desmatamento e intensificar a pressão que os fragmentos florestais já sofrem para aumentar a área de plantio a fim de compensar a baixa produtividade". Por essa razão, em determinadas plantações, a diminuição da área com vegetação nativa nas propriedades privadas, como permitido no Novo Código, exigirá maior área de plantio para compensar a redução da produtividade, aumentando o desmatamento.

Além dessa questão, Ab'Sáber (2010, p. 333) destaca que a Lei 12.651/12 "defende um processo que significará uma onda de desmatamento e emissões incontroláveis de gás carbônico". Para o autor,

A utopia de um desenvolvimento com o máximo de floresta em pé não pode ser eliminada por princípio em função de mudanças radicais no Código Florestal, sendo necessário pensar o território total de nosso país, sob um ampliado e correto Código da Biodiversidade. (AB'SÁBER, 2010, p. 335).

O atual Código Florestal pouco contribui para a proteção e preservação dos distintos ecossistemas e recursos naturais em território nacional, sendo mais eficiente aos interesses econômicos momentâneos que às questões ambientais, visto que o aumento de desmatamento promove perdas na qualidade e quantidade de água, na formação de processos erosivos que diminuem a fertilidade e causa a perda de solos, na redução do habitat de insetos polinizadores, e esses fatores diminuem significativamente a produtividade agrícola a médio e longo prazo. 
Os códigos florestais, ao estabelecerem faixas de proteção para as Áreas de Preservação Permanentes e uma parte da propriedade como Reserva Legal, como instrumentos de planejamento ambiental para regular o uso e ocupação da terra de forma sustentável, criam o mecanismo do zoneamento no interior das propriedades rurais sem levar em consideração os diferentes biomas e ecossistemas do território nacional e inúmeros aspectos do meio físico.

Quanto a essa problemática e a necessidade de se repensar o Código Florestal mediante as características físicas dos distintos ambientes existentes em território nacional, propõe-se um estudo aplicado e comparativo das restrições ao uso nas propriedades privadas de acordo com o atual Código Florestal e com o zoneamento ambiental elaborado a partir da metodologia da Geoecologia da Paisagem, aplicados na alta bacia do ribeirão Areia Dourada, Marabá Paulista (SP). Assim, temse como objetivo: identificar as diferenças espaciais na restrição ao uso da terra existente entre a Lei 12.651/12 e a metodologia da Geoecologia, sendo que essa se caracteriza por integrar os diversos elementos que compõem a paisagem.

O zoneamento compreende uma ferramenta na identificação de áreas críticas em relação ao uso das terras, com respaldo em mecanismos disciplinadores e técnicas que minimizem os efeitos da ação antrópica no meio (OLIVEIRA, 2003). A concepção geoecológica emprega o método sistêmico na análise do meio e permite compreender a paisagem como resultado do conjunto de processos físico-naturais e a forma como os grupos sociais utilizam, transformam e percebem essa paisagem natural (MATEO-RODRIGUEZ et al., 2004). Assim, ao aplicar a referido método para elaboração do zoneamento, avaliam-se as fragilidades naturais, as transformações promovidas pelas diversas atividades antrópicas e suas consequências para o ambiente.

$\mathrm{Na}$ interação sociedade-natureza, a ação humana, ao interferir nos fluxos naturais de energia, matéria e informação (E.M.I), torna-se um elemento integrante do sistema. A influência no sistema natural depende do nível de (des) organização social que, por sua vez, causa menor ou maior alteração no sistema, sendo a resposta do ambiente dependente da intensidade das alterações impostas e da distância entre essas transformações e o equilíbrio natural, o que pode gerar a otimização dos processos naturais, bem como a degradação dos recursos naturais (Figura $1)$. 
Figura 1: Sequência do processo de degradação dos geossistemas.

\begin{tabular}{|c|c|c|c|c|c|c|c|}
\hline $\begin{array}{c}\text { CLIMA } \\
\text { Processo } \\
\text { climabiogenético }\end{array}$ & $\begin{array}{l}\text { Vegetação } \\
\text { Climax }\end{array}$ & & $\begin{array}{l}\text { Desflorestamento, } \\
\text { desaparecimento da } \\
\text { vegetação natural }\end{array}$ & & $\begin{array}{l}\text { Cultivo incontrolado } \\
\text { Aparecimento de pragas } \\
\text { e enfermidades }\end{array}$ & & $\begin{array}{l}\text { Perda do umbral e } \\
\text { capacidade produtiva } \\
\text { e de potencial genético }\end{array}$ \\
\hline $\begin{array}{l}\text { RELEVO } \\
\text { Morfogênese }\end{array}$ & $\begin{array}{l}\text { Morfogênese } \\
\text { atenuada }\end{array}$ & & $\begin{array}{l}\text { Maior escoamento } \\
\text { Menor infiltração }\end{array}$ & & Erosão hídrica e eólica & & $\begin{array}{c}\text { Desequilibrio hidrológico, } \\
\text { desertificação e outros } \\
\text { processos }\end{array}$ \\
\hline $\begin{array}{c}\text { SOLO } \\
\text { Pedogênese }\end{array}$ & $\begin{array}{l}\text { Pedogênese } \\
\text { ativa }\end{array}$ & & $\begin{array}{l}\text { Degradação físico- } \\
\text { biológica }\end{array}$ & & Perda de nutrientes & & $\begin{array}{l}\text { Salinização hidromórfica } \\
\text { e outros processos }\end{array}$ \\
\hline $\begin{array}{c}\text { PAISAGEM } \\
\text { Gênese e } \\
\text { desenvolvimento } \\
\text { da paisagem }\end{array}$ & $\begin{array}{l}\text { Paisagem em } \\
\text { estabilidade } \\
\text { homeostática }\end{array}$ & & $\begin{array}{l}\text { Paisagem no primeiro } \\
\text { estágio de alteração das } \\
\text { relações homeostáticas. } \\
\text { Ainda está quase intacto } \\
\text { o potencial natural e a } \\
\text { integridade. } \\
\text { A estabilidade natural } \\
\text { se modifica } \\
\text { antropogenicamente }\end{array}$ & & $\begin{array}{c}\text { Paisagem instável à crítica } \\
\text { que experimentou a perda } \\
\text { parcial da estrutura espacial } \\
\text { e funcional e da integridade } \\
\text { que dá lugar à } \\
\text { desestruturação (alteração) } \\
\text { das relações homeostáticas }\end{array}$ & & $\begin{array}{l}\text { Paisagem esgotada em } \\
\text { estado muito critico que } \\
\text { perdeu a estrutura } \\
\text { espacial e funcional. } \\
\text { Os mecanismos da } \\
\text { estabilidade natural } \\
\text { foram eliminados }\end{array}$ \\
\hline $\begin{array}{l}\text { SISTEMA } \\
\text { AGRÍCOLA }\end{array}$ & $\begin{array}{l}\text { Geossistema } \\
\text { natural }\end{array}$ & & $\begin{array}{c}\text { Sistema agricola } \\
\text { adaptado. Produtividade } \\
\text { alta ou baixa } \\
\text { (em dependência do } \\
\text { ingresso de energia } \\
\text { externa) }\end{array}$ & & $\begin{array}{c}\text { Sistema agrícola de } \\
\text { compromisso. Produtividade } \\
\text { média a muito alta } \\
\text { (em dependência do } \\
\text { ingresso de energia externa) }\end{array}$ & & $\begin{array}{c}\text { Sistema agricola } \\
\text { desintegrado. } \\
\text { Produtividade baixa ou } \\
\text { muito baixa (inclusive em } \\
\text { dependência de ingresso } \\
\text { de energia externa) }\end{array}$ \\
\hline $\begin{array}{c}\text { NIVEL DE } \\
\text { DEGRADAÇÃO }\end{array}$ & Sem degradação & & Pouco degradada & & Degradada & & Muito degradada \\
\hline
\end{tabular}

Fonte: Mateo-Rodriguez et al., 2004, p.140.

De acordo com a Figura 1, ao analisar a paisagem mediante o método sistêmico, entendese que essa possui dinâmica própria, com ritmo ditado pelo clima em suas variações sazonais e o funcionamento relacionado às características litológicas, geomorfológicas, pedológicas e da cobertura vegetal natural, que configuram a estrutura. Nessainteração, o sistemanatural tendeahomeostasia, em estado de equilíbrio dinâmico, em que o input de E.M.I., ao ser processado pela estrutura do sistema gera um output - este é evacuado pelo sistema próximo ao que foi adicionado. Ou seja, da mesma forma em que a ação do calor, da chuva e da água corrente desagrega e carrega para fora do sistema materiais particulados do solo, o intemperismo físico e químico, mais a produção de húmus, equilibram essa equação, produzindo solo pela decomposição do material de origem e da matéria orgânica proveniente das espécies vegetais. Quanto ao ciclo hidrológico, a vegetação assume a função de conter o escoamento superficial, melhorar a infiltração do solo e reter água no ambiente, compensando a água escoada, evaporada ou evapotranspirada para fora do sistema.
As paisagens resultam da combinação diferenciada dos elementos que as compõem, visto que Litologias e formas de relevo interferem e geram distintas classes de solos que abrigam diferentes espécies vegetais. Essa diversidade de situações torna os terrenos mais ou menos suscetíveis à ação do clima, principalmente a intensidade, a magnitude e a frequência das chuvas, tendendo em menor ou maior grau ao desenvolvimento de processos geomórficos. Assim, a sociedade, ao empregar sua cultura na natureza, altera alguns de seus elementos e, consequentemente, os ciclos naturais para satisfazer suas necessidades. Desse modo, ela pode intensificar os processos de degradação ambiental, modificando fluxos de E.M.I. e rompendo o equilíbrio dinâmico, o que gera evacuação de elementos maior do que os inputs processados no sistema podem repor.

Ao analisar a paisagem mediante a integração dos diversos elementos que a compõem, pode-se compreender seu funcionamento e elaborar um zoneamento ambiental com base nessa proposta. A partir dela, gera-se como produto cartográfico a espacialização das áreas com maior ou menor 
vulnerabilidade a processos geomórficos, o que contribui para entender a dinâmica natural da área e, assim, indicar o potencial de uso com base na capacidade de suporte dos terrenos. Além disso, tal estudo possibilita levantar as tendências ou consequências do uso inadvertido do meio, o que permite comparar não apenas com o zoneamento segundo o novo Código Florestal, mas também identificar os problemas que resultam de sua aplicabilidade.

\section{A alta bacia do ribeirão areia dourada, marabá paulista (sp)}

Localizada no extremo W do estado de São Paulo, no Planalto Ocidental Paulista e na bacia sedimentar do Paraná, sobre Formações areníticas e clima tropical úmido, a alta bacia do ribeirão Areia Dourada abrange área de $46 \mathrm{~km}^{2}$ inteiramente no município de Marabá Paulista (SP) (Figura 2).

Figura 2: Localização da alta bacia do ribeirão Areia Dourada, Marabá Paulista (SP).

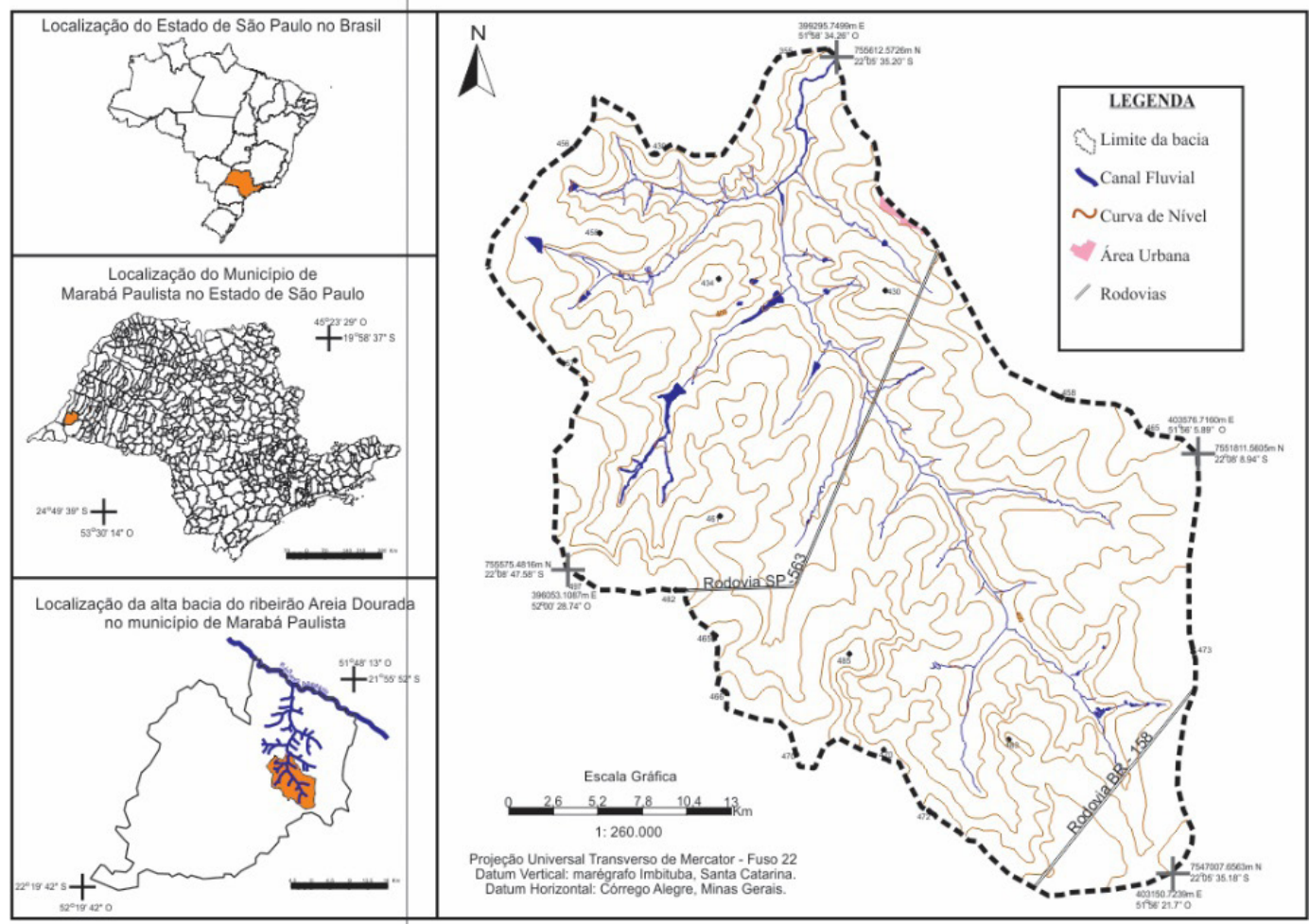

Org.: os autores.

A forma assimétrica da bacia reflete a acomodação das placas tectônicas à falha geológica que originou o rio Paraná, interferiu e formou o traçado de seus afluentes e subafluentes, dentre esses o ribeirão Areia Dourada, com falhas da nascente até sua foz, nas posições SSE-NNW com inflexão de SSW-NNE. Esses movimentos tectônicos potencialmente caracterizaram as formas do relevo da área, onde o setor $\mathrm{W}$ apresenta maiores altitudes, topos estreitos, vertentes extensas e rede de drenagem mais desenvolvida em relação à porção $\mathrm{E}$, com topos amplos, vertentes estreitas e canais fluviais, de no máximo segunda ordem.

Nessa bacia, as formas de relevo apresentam relação estreita também com as características geológicas, visto que estas interferem no desenvolvimento das distintas classes de solos encontradas na área. Nos terrenos sobre Litologias da Formação Adamantina, o relevo é pouco dissecado, o que permitiu o desenvolvimento de Latossolo Vermelho Álico nas vertentes do setor W e nos topos amplos. Nos locais onde as Litologias da referida 
Formação apresentam maior resistência, como a SW e NW, ocorrem topos com Neossolo Litólico Eutrófico.

$\mathrm{Na}$ média vertente e na transição dos topos amplos para alta vertente, a diferença de resistência de litofácies da Formação Adamantina promove o surgimento de rupturas topográficas abruptas, com os terrenos a jusante apresentando declividade $\geq 20 \%$. A NNW, litofácies intercaladas de bancos arenosos, de alta permeabilidade, e bancos silto-argilosos, de baixa permeabilidade, causam o afloramento d'água na vertente, com manchas de solos subordinados ao hidromorfismo e escoamento de água para jusante, formando filetes de água perenes de baixa vazão e intermitentes que abastecem os rios a jusante.

Exceto na porção Centro-Oeste, nas demais vertentes da bacia, em Litologias menos resistentes da Formação Adamantina, o relevo é mais dissecado e ocorre a formação de Argissolo Vermelho Distrófico. Já na baixa vertente, próximo aos fundos de vale, a erosão removeu os sedimentos da Formação Adamantina e os solos se desenvolveram sobre a Formação Santo Anastácio. Esta Formação se caracteriza pela deficiência de material pelítico, que resulta em baixa agregação das frações granulométricas.

Em todas as classes de solos presentes na bacia, a composição é predominantemente de frações de areia, com aproximadamente $80 \%$, principalmente de areia fina (CARVALHO, 1997). Sobre esses solos, as espécies vegetais que se desenvolveram exerceram maior proteção à ação das chuvas, principalmente as prolongadas e de maior magnitude que ocorrem na primavera e no verão (BOIN, 2000). A vegetação nativa dos Biomas Mata Atlântica e Cerrado, além de servirem como anteparo na proteção dos solos contra a ação direta das gotas d'água, através da produção de húmus na decomposição da matéria orgânica, geraram maior concentração de carbono orgânico nos horizontes superficiais, formando agregados que melhoraram a estruturação do solo, aumentaram a resistência à desagregação e a capacidade de infiltração, o que diminui a ação do efeito erosivo pela redução do escoamento superficial.

Quanto à ação antrópica na região, no final do século XIX e início do século XX ocorreu a chamada marcha para o W do estado de São Paulo, promovida por alianças entre grileiros e políticos, e intensificada pela construção da Estrada de Ferro Alta Sorocabana. De acordo com Monbeig (1984) e Ferrari Leite (1998), a principal característica desse processo de ocupação foi sua intensidade: iniciada mediante genocídio étnico contra os povos indígenas e a remoção predatória da vegetação nativa.

O genocídio promovido aos povos tradicionais, que habitavam a região há séculos e detinham conhecimentos das características naturais da área, e a implantação forçada do modelo europeu de monocultivo vinculado à exportação, impediu maior conhecimento da área para realizar uma ocupação mais adequada, o que gerou estado de desequilíbrio dos sistemas naturais. A substituição quase que completa da vegetação nativa proporcionou a perda da constante reposição de húmus nos solos arenosos, a capacidade do ambiente de dissipar o fluxo das águas pluviais e reduziu a proteção contra a ação erosiva das chuvas, expondo os terrenos à dinâmica geomórfica promovida pela energia cinética das gotas d'água e concentração do escoamento das águas pluviais, resultando em processos erosivos lineares em sulcos, ravinas e voçorocas e em alterações nos canais fluviais em toda a região.

O atual uso e cobertura superficial da terra (2013) na alta bacia do ribeirão Areia Dourada indica que esse modelo de uso do início da ocupação da região ainda se faz presente na área estudada, pois se observou vegetação nativa em apenas $0,69 \%$, cultivo da cana-de-açúcar em $31,26 \%$ e pastagens em $54,72 \%$ dos terrenos da bacia.

Como consequência desse modelo de uso da terra aplicado às características naturais da alta bacia do ribeirão Areia Dourada, Zanatta et al. (2015) identificaram que, de 1962 para 2013, as feições erosivas lineares aumentaram de 136 para 530, sendo 138 ravinas e sete voçorocas, além de alterações na rede de drenagem, de 29 para 71 canais fluviais, e na área deposicional dos fundos de vale, que ampliaram de 64,67 ha para 112,28 ha, consequentes das sucessivas e intensivas atividades antrópicas. De acordo com os autores, os usos estabelecidos ao longo dos anos analisados e a substituição quase completa da vegetação nativa intensificaram os 
fluxos de matéria e energia, ao mesmo tempo em que diminuíram a resistência do meio, forçando a readaptação da bacia mediante processos erosivos lineares, o que resultou no aumento da quantidade de sedimentos carregados para os fundos de vale e ampliação dos canais de primeira ordem, alterando a ordem dos canais da bacia e alargando as áreas de planície e terraço fluvial dos canais de ordem superior. Não apenas a substituição da vegetação nativa e os usos excessivos influenciaram nessas mudanças, os terraços agrícolas a montante de afloramentos d'água na vertente a NNW da bacia aumentaram a quantidade de água infiltrada e consequentemente expandiram os afloramentos e o número de canais que escoam a jusante.

É nesse cenário que o zoneamento proposto pela Geoecologia da Paisagem será comparado às Áreas de Preservação Permanente definidas a partir do novo Código Florestal (Lei 12.651/12), com o objetivo de identificar as respectivas deficiências e eficiências em relação as características da área estudada e aos princípios norteadores presentes na Constituição Federal Brasileira de 1988, quanto a função social no uso dos recursos naturais (Cap. III, Art. 186, Inciso II) e o direito de todos, inclusive das futuras gerações, a um ambiente ecologicamente equilibrado (Cap. VI, Art. 225).

\section{MATERIAIS E TÉCNICAS CARTOGRÁFICAS}

Os procedimentos cartográficos descritos nesse tópico foram trabalhados no software livre SPRING 5.1.3, no qual foram obtidos também os dados espaciais quantitativos por meio da ferramenta medida de classes.

Tanto no mapeamento das APP's, de acordo com o Código Florestal (Lei 12.651/12), como da capacidade de uso, seguindo a proposta da Geoecologia da Paisagem (MATEO-RODRIGUEZ et al., 2004), foi utilizada como base cartográfica os dados topográficos das cartas do IBGE (Instituto Brasileiro de Geografia e Estatística) de 1976, em escala 1:50.000, folhas de Marabá Paulista (SF22-Y-B-II-1) e Ribeirão das Anhumas (SF-22-YB-I-2). Destas, foram vetorizadas as curvas de nível, com equidistância de vinte metros, adicionados os respectivos valores altimétricos, e os pontos cotados. Já o levantamento da hidrografia (nascentes e canais perenes) foi realizado a partir da fotointerpretação das fotografias SF-22-YB-I2-NE, SF-22-Y-B-II1-NO, SF-22-Y-B-II-1-SO e SF-22-YB-I-2-NE do aerolevantamento realizado pela Empresa Paulista de Planejamento Metropolitano SA (EMPLASA) em 2010, reambulados em campo nos anos de 2011, 2012 e 2013.

\section{Aplicação e cartografia do Novo Código Florestal (Lei 12.651/12)}

Para aplicação da Lei 12.651/12, no que se refere às Áreas de Preservação Permanente, foi necessária a identificação dos canais fluviais, nascentes, reservatórios artificiais e os limites das propriedades rurais, com o respectivo tamanho em Módulo Fiscal.

Segundo a referida lei, o marco inicial na demarcação das APP's dos canais fluviais é o "leito regular" (BRASIL, 2012, Art. 4º), definido como "calha por onde correm regularmente as águas do rio durante o ano" (BRASIL, 2012, Art.3을 Inciso XIX, alínea " $k$ "). De acordo com estudos da geomorfologia fluvial, essa definição se assemelha ao leito vazante dos rios, que se refere "à parte do canal ocupada durante o escoamento das águas de vazante (estação seca). Suas águas divagam dentro do leito menor seguindo o talvegue, que é a linha de máxima profundidade ao longo do leito e que é mais bem identificada na seção transversal do canal" (Torres et al., 2012, p.149) (Figura 3). 
Figura 3: Exemplo de identificação em fotografia aérea e em campo de nascentes, do leito regular e da área de acumulação artificial de água. (A) Nascente; (B) leito regular ou vazante.

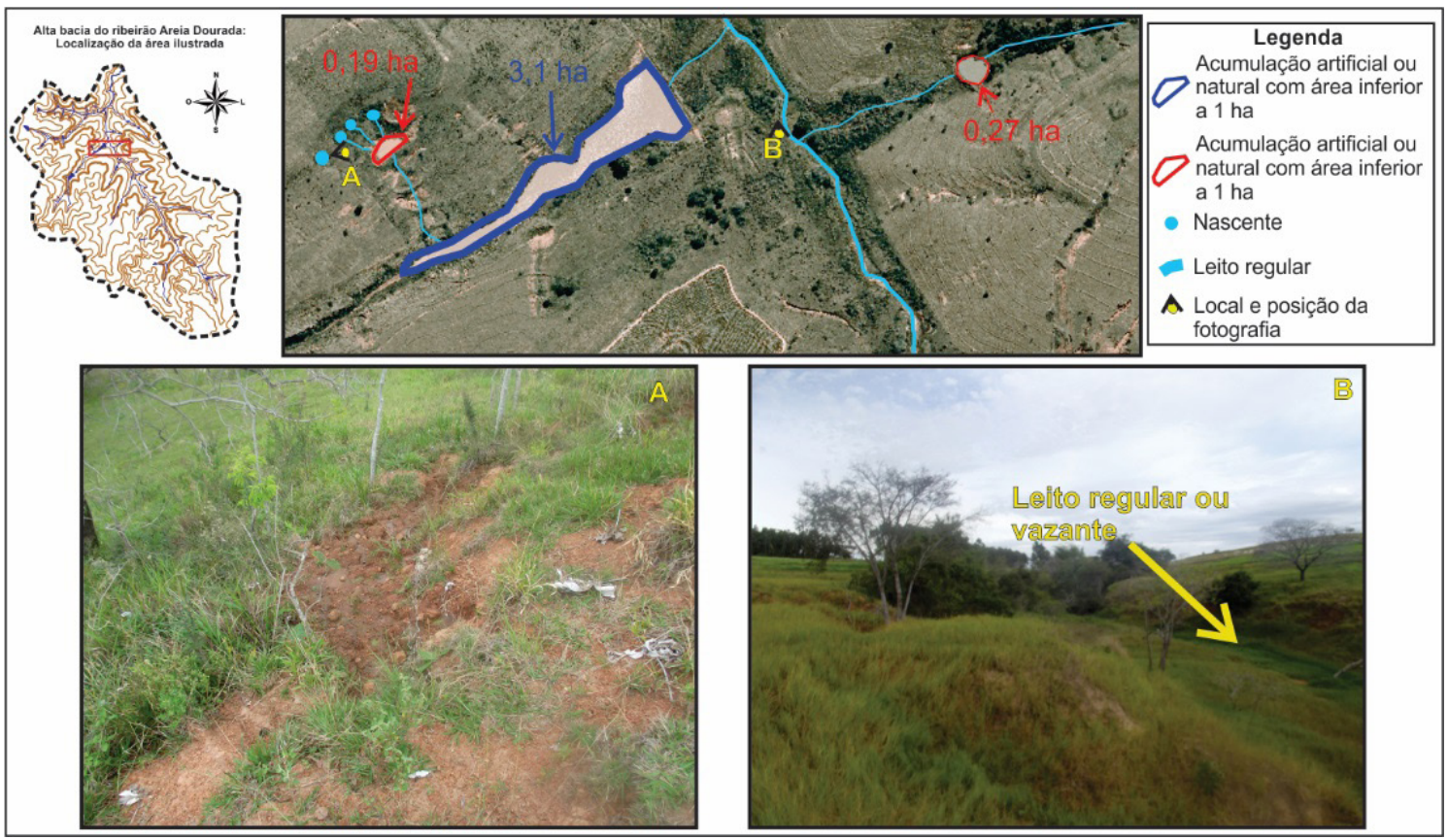

Org.: os autores.

Para os reservatórios artificiais, o Art. $4^{\circ}, \S 4^{\circ}$ define que "nas acumulações naturais ou artificiais de água com superfície inferior a 1 (um) hectare, fica dispensada a reserva da faixa de proteção", já para os com área acima de um hectare, no Incido III do Art. $4^{\circ}$, considera que o limite da APP é "a faixa definida na licença ambiental do empreendimento". A área das acumulações artificiais de água foi calculada a partir da ferramenta Operações Métricas, no entanto, de modo a não ter acesso à licença ambiental do empreendimento, tampouco averiguado em campo a presença de alguma preservação nessas áreas, optouse por não projetar a APP naquelas com área superior a um hectare.

No caso das nascentes, o atual Código Florestal define no Art. $4^{\circ}$, Inciso IV, que as APP's devem ocupar "o entorno das nascentes e dos olhos d'água perenes, qualquer que seja sua situação topográfica, no raio mínimo de 50 metros".
Considerando da definição proposta "qualquer situação topográfica", interpretou-se como nascente as feições de afloramentos d'água que surgem nas vertentes, característico de Litologias areníticas da área estudada. Esses afloramentos originam a filetes de água perenes (Figura 4). 
Geoecologia Da Paisagem X Legislação Ambiental: Uma Análise Da Distribuição Espacial Das Restrições Ao Uso Da Terra Frente À

Problemática Erosiva Na Alta Bacia Do Ribeirão Areia Dourada, Marabá Paulista (Sp)

Felipe Augusto Scudeller Zanatta, Cenira Maria Lupinacci, Marcos Norberto Boin

Figura 4: Exemplo de identificação em fotografia aérea e em campo do afloramento d'água na vertente como nascente. (A) Afloramento d'água na vertente. (B) Afloramento de água na vertente originando filetes de água perenes.

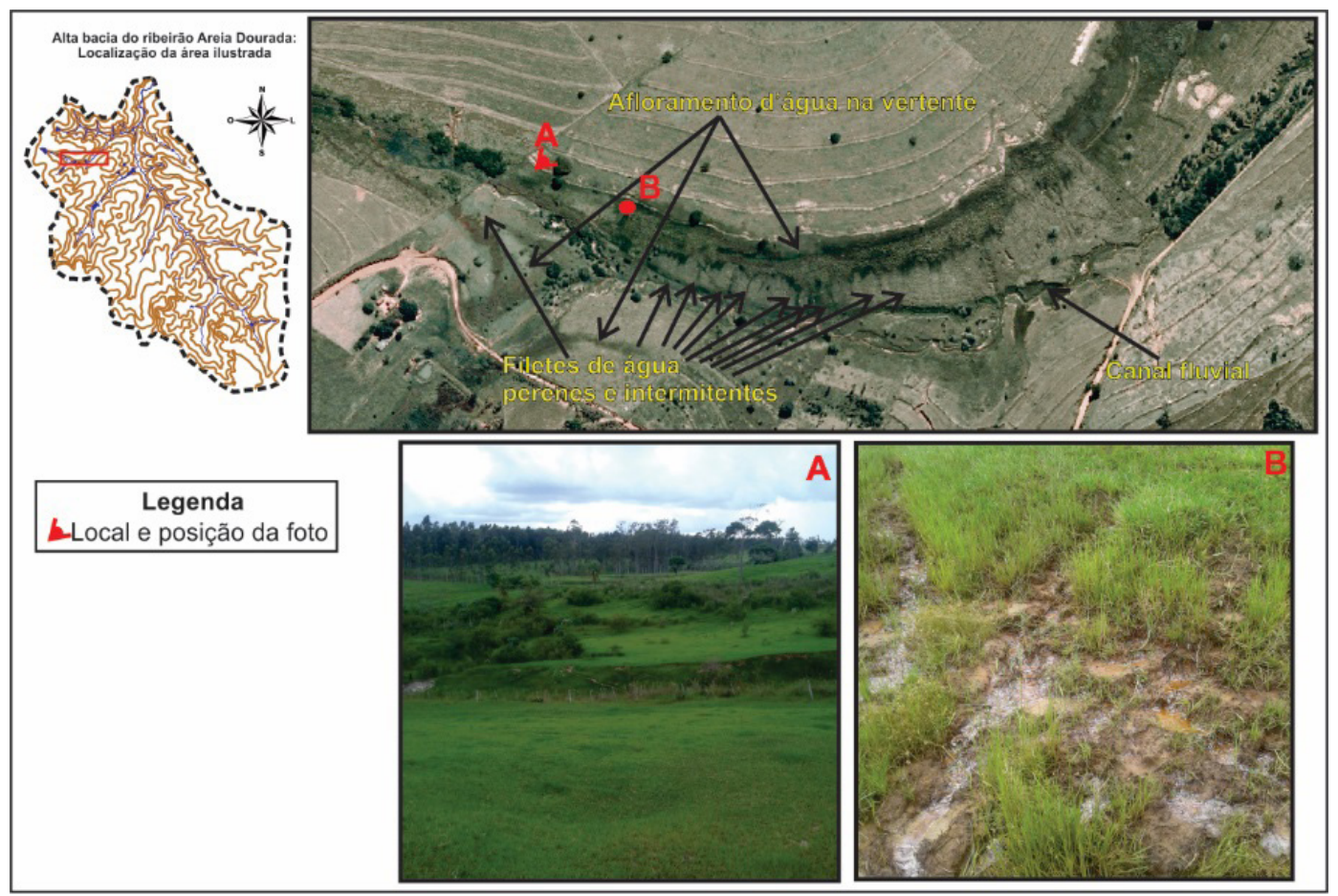

Org.: os autores.

No texto legal, a medida da APP é alterada em caso de área rural consolidada, na qual fica autorizada a continuidade das atividades em parte da APP com "ocupação antrópica preexistente a 22 de julho de 2008, com edificações, benfeitorias ou atividades agrossilvipastoris, admitida, neste último caso, a adoção de regime de pousio" (BRASIL, 2012 Art. $3^{\circ}$, Inciso IV). No caso da APP em área consolidada em nascentes e olhos d'água perenes, o $\S 5$ estabelece a proteção de um raio mínimo de 15 metros. Ainda, nas propriedades rurais enquadradas na situação descrita, as APP's de canais fluviais são reduzidas em consonância com o Módulo Fiscal, sendo: cinco metros para imóveis rurais com até um Módulo Fiscal; oito metros para imóveis rurais com área superior a um e até dois Módulos Fiscais; quinze metros para imóveis rurais com área superior a dois e até quatro Módulos Fiscais (BRASIL, 2012, Art. 61-A). Para imóveis rurais com área superior a quatro Módulos Fiscais é obrigatória a recomposição das respectivas faixas de acordo com o leito regular e nascente, sem redução da APP. O tamanho do Módulo Fiscal, estabelecido a partir da Lei ${ }^{0} 6.746 / 79$, no município de Marabá Paulista, equivale a 30 hectares.

Após levantamentos das áreas rurais consolidadas, através da fotointerpretação e de trabalhos de campo, e do tamanho das propriedades, através da ferramenta Operações Métricas, as APP's foram traçadas, seguindo as referidas orientações da Lei, por meio da ferramenta mapa de distâncias.

\section{Aplicação e cartografia da Geoecologia da Paisagem}

De acordo com a proposta teórica de MateoRodrigues et al. (2004) e as aplicações da metodologia da Geoecologia da Paisagem realizadas por Leal (1995) e Oliveira (2003), foram coletadas, a partir de fontes secundárias e primárias, o maior número de informações mapeadas do meio físico que abrangem a área estudada. Assim, levantaram-se os dados de geologia, solos, morfometria e formas de relevo.

Os dados geológicos foram extraídos 
do trabalho de Stein (1999), o qual, a partir do levantamento da geologia da bacia do Rio Santo Anastácio em escala 1: 250.000 realizado pelo IPT (Instituto de Pesquisas tecnológicas do Estado de São Paulo) em 1994, reambulou para escala 1: 100.000, ajustando os limites das formações.

Os dados de solos foram obtidos do trabalho coordenado por Carvalho (1997), a qual utilizou fotografias do aerolevantamento de Presidente Venceslau de 1997, escala de voo 1: 35.000, e coleta de amostras em campo. A referida autora elaborou a carta de solos da bacia do Rio Santo Anastácio na escala de semidetalhe, 1: 100.000. Esses dados foram reambulados em campo e atualizados a partir da interpretação das fotografias da EMPLASA (2010), com ajuste do limite dos Gleissolos Háplicos e adicionada a classe de solos subordinados ao hidromorfismo, em terrenos com afloramento d'água na vertente.

Quanto ao relevo, a morfometria foi adquirida do trabalho de Boin et al. (2014), os quais utilizaram a proposta de Mendes (1993) para elaborar a carta de energia do relevo. Os autores tiveram como base as cartas topográficas do IBGE, em escala 1: 50.000. Esses dados foram complementados com outros, referentes à compartimentação morfológica da área, delimitando os setores de topo, as formas de vertentes retilíneas, côncavas e convexas e os fundos de vale, por meio da interpretação dos contornos das curvas de nível e, para o caso dos fundos de vale, pela interpretação das fotografias aéreas de 2010.

A partir desses dados, elaborou-se a carta de Unidades Físicas, a qual objetiva indicar na bacia estudada as áreas com características similares que, por isso, potencialmente apresentem respostas semelhantes às alterações impostas. Desta forma, sobrepondo os polígonos de Litologias, solos, formas e energia do relevo foram criados novos polígonos, classificando-os de acordo com a combinação dos elementos, por exemplo: Topo em Formação Adamantina e energia do relevo fraca com Latossolo Vermelho; Vertente Côncava em Formação Santo Anastácio e energia do relevo de forte a muito forte com Neossolo Litólico. Assim, individualizando todas as combinações possíveis entre os elementos adquiriu-se um total de 56 Unidades Físicas, as quais foram organizadas de forma hierárquica pela respectiva fragilidade natural que um elemento ou a combinação dos elementos deflagravam a unidade (Figura 5).

Figura 5: Trecho da carta de Unidades Físicas da alta bacia do ribeirão Areia Dourada Marabá Paulista (SP).

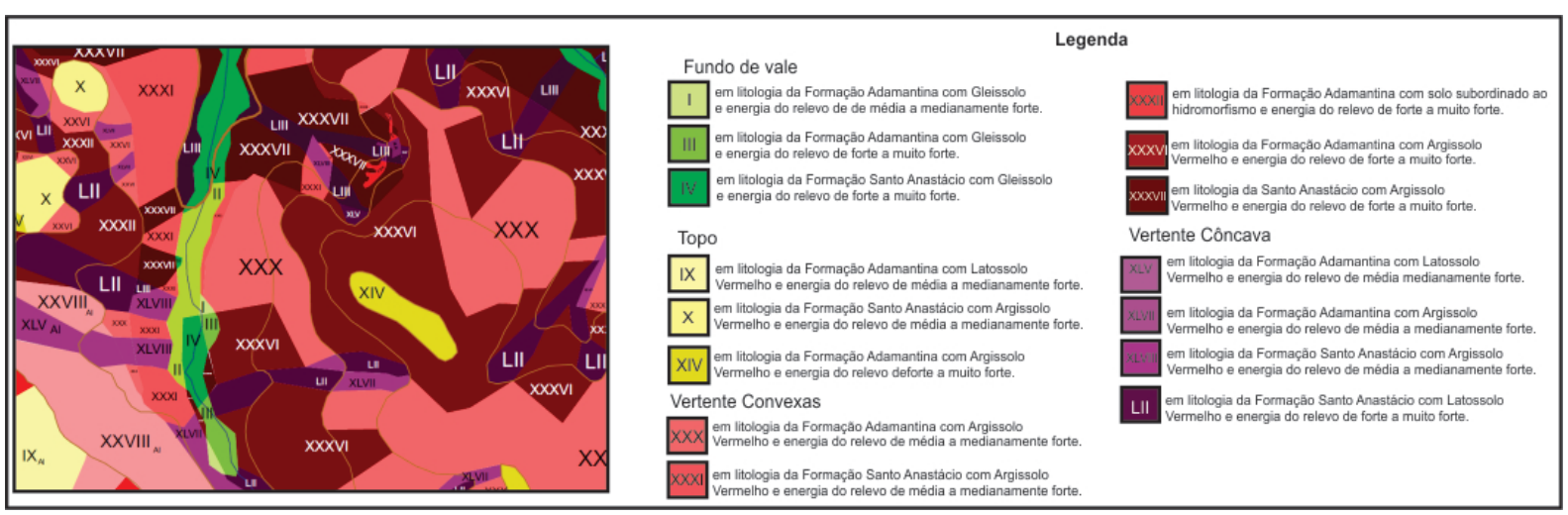

Org.: os autores. 
Posteriormente, as 56 unidades físicas, ao serem analisadas frente à fragilidade natural, foram avaliadas e distribuídas em três classes de capacidade de uso: alta, média e baixa restrição. $\mathrm{Na}$ classe alta restrição encontram-se as unidades que carecem da proteção da vegetação nativa, tanto pelo risco de contaminação direta dos corpos d'água (áreas de planície e terraço fluvial ou com solos subordinados ao hidromorfismo), como pela vulnerabilidade significativa ao desenvolvimento de processos denudativos, (energia do relevo muito forte ou Neossolo Litólico ou Litólico Eutrófico ou vertentes côncavas). Já na média restrição, foram identificas as unidades que apresentam características que permitem o uso da terra sem grandes riscos de perda de recursos naturais, desde que sejam realizados manejos adequados do solo e as coberturas superficiais promovam a dissipação do escoamento superficial e a proteção adequada dos solos predominantemente arenosos. Nessa classe encontram-se as unidades com energia do relevo de média a medianamente forte e/ou Argissolo Vermelho Distrófico ou Latossolo Vermelho Áplico e/ou topo, vertente convexa ou retilínea. Nas unidades com baixa restrição, apenas duas combinações das unidades físicas, que variam apenas quanto à geologia, foram enquadradas: topo em Litologias da Formação Adamantina ou Santo Anastácio e energia do relevo fraca, com Latossolo Vermelho Álico. Nesses terrenos os usos diversificados são possíveis, desde que sejam realizados manejos adequados ao solo, garantindo boa infiltração de água e regulação do fluxo de água superficial e subsuperficial.

Junto às classes de capacidade de uso levantadas foram acrescidas feições erosivas lineares, identificando-as como: em sulco, pequena incisão vertical no terreno; em ravina, quando a incisão atinge uma profundidade que impede o manejo agrícola da área; e em voçoroca, quando o processo erosivo provoca o afloramento do lençol freático (Figura 6). Essa sobreposição foi realizada a fim de comparar a fragilidade natural da bacia com as consequências de usos inadvertidos.

Figura 6: Exemplo de identificação das feições erosivas lineares.

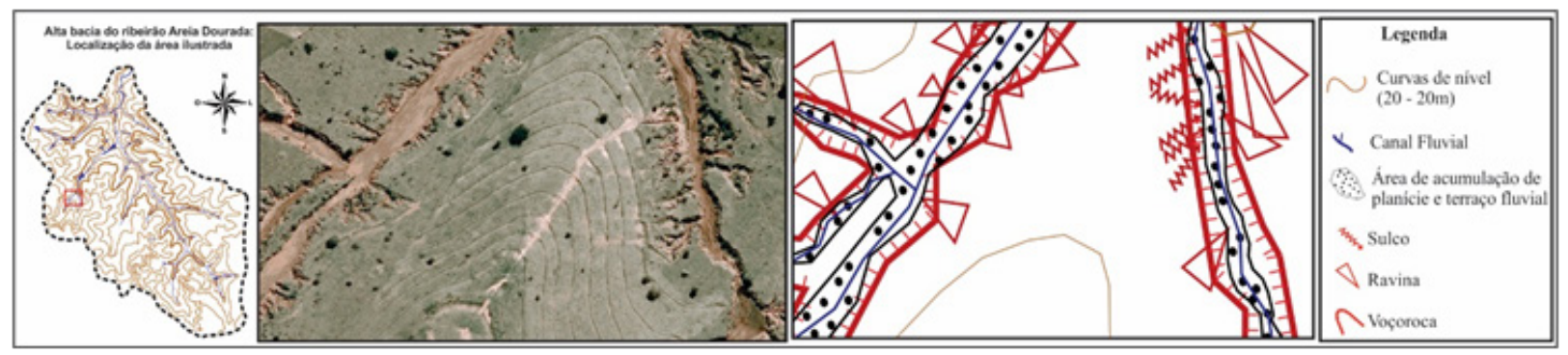

Org.: os autores.

\section{RESULTADOS}

De acordo com a Lei 12.651/12, na alta bacia do ribeirão Areia Dourada foram consideradas APP's apenas as margens dos canais fluviais e das nascentes (Figura 7). 
Geoecologia Da Paisagem X Legislação Ambiental: Uma Análise Da Distribuição Espacial Das Restrições Ao Uso Da Terra Frente À Problemática Erosiva Na Alta Bacia Do Ribeirão Areia Dourada, Marabá Paulista (Sp)

Figura 7: Carta de Áreas de Preservação Permanente, Lei 12.651/2012, da alta bacia do ribeirão Areia Dourada, Marabá Paulista (SP).

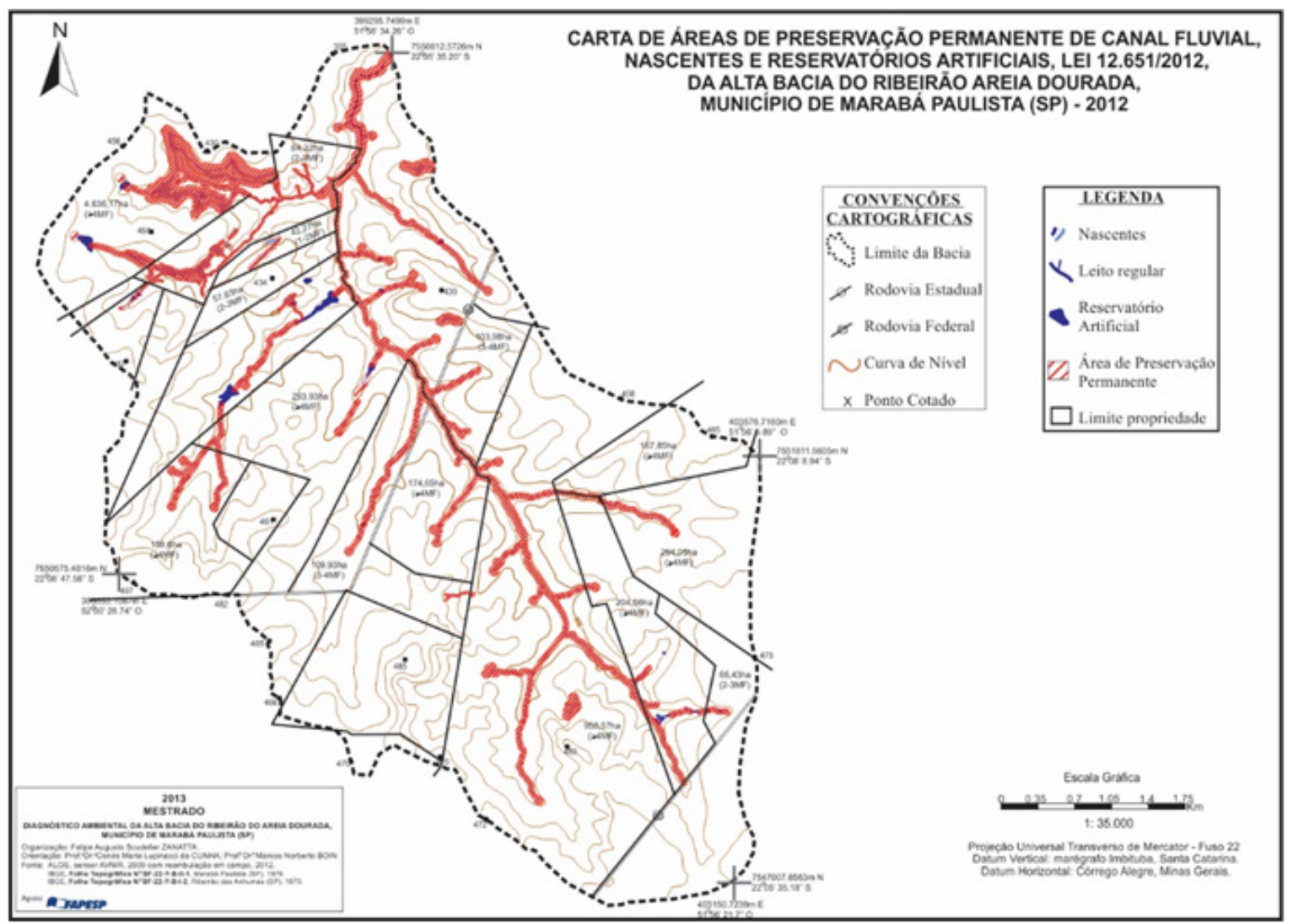

Org.: os autores.

Do atual Código, como ilustra a Figura 7, são poucos os terrenos considerados como APP's, as quais abrangem apenas $6,28 \%(290,55 \mathrm{ha})$ da área estudada. Assim, de acordo com a Lei, os demais $93,72 \%$ da bacia estão à disposição das mais distintas atividades antrópicas.

Em face da Lei não considerar a dinâmica fluvial, com o leito maior dos rios como marco inicial das APP's de canais fluviais, na alta bacia do ribeirão Areia Dourada averiguou-se dentro dessas APP's 64,75 ha de vegetação com influência fluvial ou de afloramento d'água e 2,07 ha de bancos de areia, ou seja, $23 \%$ do total das APP's estão inseridos na dinâmica fluvial da bacia. Essa situação, ainda, expõe áreas de planície e terraço aluvial a ação antrópica, como identificado na foz do ribeirão Areia Dourada (Figura 8), o que coloca em risco os recursos hídricos através da contaminação direta, seja pela pecuária ou insumos da agricultura, dos cursos d'água da bacia. 
Geoecologia Da Paisagem X Legislação Ambiental: Uma Análise Da Distribuição Espacial Das Restrições Ao Uso Da Terra Frente À

Problemática Erosiva Na Alta Bacia Do Ribeirão Areia Dourada, Marabá Paulista (Sp)

Felipe Augusto Scudeller Zanatta, Cenira Maria Lupinacci, Marcos Norberto Boin

Figura 8: Perfil topográfico da Área de Preservação Permanente, da planície aluvial e das vertentes na foz do ribeirão Areia Dourada, Marabá Paulista (SP)

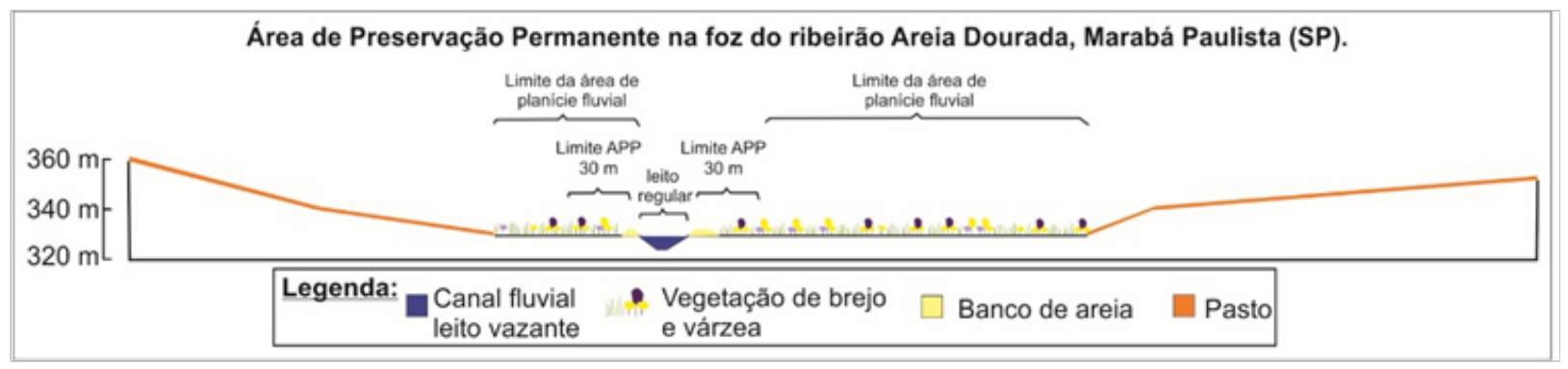

Org.: os autores.

Como constatado na Figura 8, além de boa parte da planície aluvial ficar à disposição das atividades antrópicas, as margens do leito maior estão ocupadas por pastagens, quando deveriam conter vegetação nativa para efetivamente proteger o corpo d'água, regulando a quantidade de água, nutrientes e sedimentos que chegam ao rio em períodos de chuvas, garantindo a qualidade da água, o habitat de variadas espécies vegetais e animais e a proteção dos solos nesses setores (BOIN, 2005).
Nessas condições, o caso ilustrado demonstra que a Lei 12.651/12 acaba por descumprir a função de preservar os recursos hídricos e proteger o solo que a própria Lei estabelece para as APP's.

Já no zoneamento, segundo a proposta da Geoecologia da Paisagem, as áreas com alta restrição ao uso, as quais devem ser preservadas, excedem os fundos de vale e as margens dos canais fluviais, ocupando topos, vertentes côncavas, convexas e retilíneas (Figura 9).

Figura 9: Carta de capacidade de uso da alta bacia do ribeirão Areia Dourada, Marabá Paulista (SP).

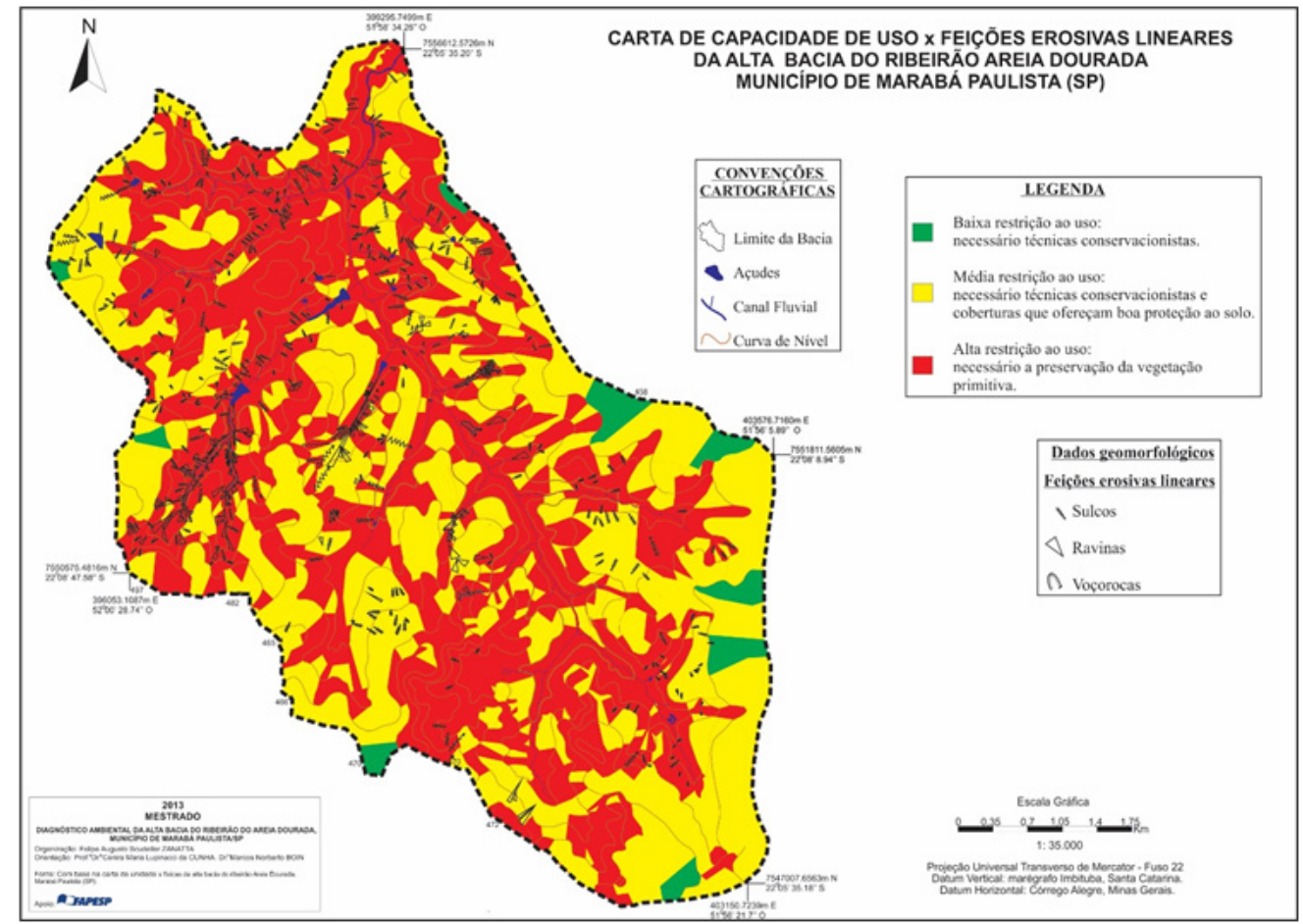

Org.: os autores. 
Quantitativamente (Tabela 1), as áreas com alta restrição ao uso ocupam 51,66\% (2.388,28 ha), o que demonstra a significativa fragilidade natural da bacia. Áreas com média restrição, localizadas em vertentes convexas, retilíneas e nos topos, abrangem 45,88\% (2.121,47 ha) do total da área estudada. Já nas áreas de baixa restrição ao uso abarcam $2,46 \%$ $(113,73$ ha) da bacia.

Tabela 1: Capacidade de uso da alta bacia do ribeirão Areia Dourada, Marabá Paulista (SP).

\begin{tabular}{|l|l|l|}
\hline \multicolumn{2}{|l|}{ Capacidade de uso } \\
\hline \multirow{2}{*}{ Restrição } & Área \\
\cline { 2 - 3 } & (ha) & $(\%)$ \\
Alta & $2.388,28$ & 51,66 \\
Média & $2.121,47$ & 45,88 \\
Baixa & 113,73 & 2,46 \\
\hline
\end{tabular}

Org.: os autores.

Quando sobrepostas as feições erosivas lineares sobre as classes de capacidade de uso (figura 5) verificou-se que, dos 388 sulcos identificados, 286 encontram-se em áreas de alta restrição, 100 em média restrição e dois em áreas de baixa restrição. Quanto às ravinas, 144 estão localizadas em área de alta restrição e 21 em área de média restrição. As sete voçorocas identificadas incidem em terrenos com alta restrição ao uso. Esses dados demonstram que as feições erosivas ocorrem com maior frequência e se desenvolvem com maior intensidade em terrenos de alta restrição. Já nas áreas de média restrição, as informações levantadas evidenciam que o uso inadequado é elemento catalisador dos processos erosivos em sulcos em ravinas. A presença de sulco em área de baixa restrição ocorre em uma única situação a NNW da bacia, o que demonstra uso excessivo do terreno, bem como indica que as feições erosivas pouco se desenvolvem nessa classe de restrição, diferentemente das demais.

\section{CONSIDERAÇÕES FINAIS}

Comparando os dados obtidos, verificou-se que, de acordo com o novo Código Florestal, as áreas que devem ser legalmente preservadas correspondem a apenas 6,28\% (290,55 ha) da bacia, sendo 8,22 vezes menor em relação ao zoneamento de acordo com a proposta da Geoecologia, em que as áreas de alta restrição ao uso correspondem a 51,66\% (2.388,28 ha). Nessa proposta, ainda foi possível indicar os terrenos passíveis de serem alterados (com média ou baixa restrição), de acordo com suas características físicas, situação inexistente no atual Código, que, de forma bem genérica e desatrelada de preocupações ambientais, estabelece os terrenos a serem preservados sem qualquer vínculo científico ou com as especificidades dos ambientes, pautandose somente na maior possibilidade de uso dos terrenos dentro de cada propriedade privada.

Embora o zoneamento proposto pela Geoecologia seja mais efetivo que o atual Código Florestal e, quando comparado às feições erosivas existente na área, apresente significativa competência, observou-se uma limitação. Através da referida proposta, não foram consideradas relações como o efeito de borda, visto que, nas margens de alguns canais fluviais os terrenos foram classificados com média restrição ao uso, quando deveriam ser considerados de alta restrição, uma vez que a presença da vegetação nativa nesses terrenos proporciona a retenção de nutrientes, como os insumos agrícolas, regulação do fluxo de água pluvial e controle da temperatura da água nos rios, impedindo a degradação 
dos recursos hídricos e do habitat natural de diversas espécies de peixes, plantas, insetos e anfíbios.

Dessa forma, considerou-se que o atual Código Florestal brasileiro tende a agravar a problemática erosiva da alta bacia do ribeirão Areia Dourada, reforçando, através da tolerância ao uso abusivo dos terrenos, o desgaste excessivo dos solos e a perda qualitativa e quantitativa dos recursos hídricos, situação que implica em descumprimento das funções estabelecidas pela própria Lei às APP's, bem como fere à Constituição Federal quanto aos direitos da sociedade em relação a questão ambiental e de responsabilidades no uso dos recursos naturais. Assim, o zoneamento proposto pela Geoecologia apresentou-se como uma ferramenta que pode contribuir com os proprietários e com as políticas públicas que visem à qualidade ambiental por meio da proteção e preservação dos recursos naturais da área estudada.

\section{REFERÊNCIAS}

AB'SÁBER, A. N. Do Código Florestal ao Código da Biodiversidade. Biota Neotropica, Campinas, v. 10, n. 4, 2010, pp. 331-335.

BOIN, M. N. Chuvas e erosão no Oeste Paulista: uma análise climatológica aplicada. Rio Claro: UNESP. 2010. Tese (Doutorado em Geociências) Programa de Pós-Graduação em Geociências e Meio Ambiente, Instituto de Geociências e Ciências Exatas, Universidade Estadual Paulista, Rio Claro, 2000.

BOIN, M. N. Áreas de Preservação Permanente: Uma visão prática. In: Centro de Apoio Operacional de Urbanismo e Meio Ambiente (org.). Manual prático de Promotoria de Justiça do meio ambiente. São Paulo: Imprensa Oficial do Estado de São Paulo, 2005, v. 2, pp. 849-861.

BOIN, M. N.; ZANATTA, F. A. S.; CUNHA, C. M. L. Avaliação da morfometria do relevo na alta bacia hidrográfica do ribeirão Areia Dourada, Marabá Paulista (SP). Caderno Prudentino de Geografia, Presidente Prudente, AGB, 2014, pp.5-26.
BRASIL. Decreto N²3.793 de 23 de janeiro de 1934. Aprova o Código Florestal, 1934.

BRASIL. Lei No 4.771, de 15 de setembro de 1965. Institui o novo Código Florestal, 1965.

BRASIL. Constituição (1988): Constituição da República Federativa do Brasil: promulgada em 5 de outubro de 1988.

BRASIL. Lei $\mathrm{N}^{\circ} 12.651$ de 25 de maio de 2012. Institui o novo Código Florestal, 2012.

BRASIL. Lei No 6.746, de 10 de dezembro de 1979. Altera o disposto nos arts. 49 e 50 da Lei No 4.504 e dá outras providências.

CARVALHO, W. A. (coord.) Levantamento semidetalhado dos solos da bacia do Rio Santo Anastácio-SP, Presidente Prudente, São Paulo: FCTUNESP, 1997.

CONNECTICUT RIVER JOINT COMMISSIONS (CRJC). Introduction to Riparian Buffers for the Connecticut River Watershed, 1998. Disponível em: <http://www.crjc.org/buffers/Introduction.pdf $>$. Acesso em: 30 jun. 2013.

FERRARI LEITE, J. A ocupação do Pontal do Paranapanema. São Paulo: HUCITEC, 1998.

IMPERATRIZ-FONSECA, M V. L.; NUNES-SILVA, P. As abelhas, os serviços ecossistêmicos e o Código Florestal Brasileiro. Biota Neotropica, Campinas, v. 10, n. 4, 2010, pp. 59-62.

INSTITUTO DE PESQUISAS TECNOLÓGICAS DO ESTADO DE SÃO PAULO (IPT). Bases técnicas para recuperação da alta bacia do Rio Santo Anastácio. $3^{\text {a }}$ fase. São Paulo: IPT. (IPT. Relatório, 1994, n. 32.257).

LEAL, A. C. Meio ambiente e urbanização na microbacia do Areia Branca - Campinas, SP. Dissertação (Mestrado) - Programa de Pós-Graduação em Geociências e Meio Ambiente, Instituto de 
Geociências e Ciências Exatas, Universidade Estadual Paulista, Rio Claro, 1995.

MATEO-RODRIGUEZ, J. M.; SILVA; E. V.; CAVALCANTI, A. P. B. Geocologia das paisagens: uma visão geossistêmica da análise ambiental. Fortaleza: Editora UFC, 2004.

MENDES, I. A. A dinâmica erosiva do escoamento pluvial na bacia do Córrego Lafon-Araçatuba-SP. 1993. Tese (Doutorado em Geografia). Faculdade de Filosofia Letras e Ciências Humanas, Universidade de São Paulo, São Paulo, 1993.

MONBEIG, P. Pioneiros e Fazendeiros de São Paulo. São Paulo: HUCITEC, 1984.

OLIVEIRA, R. C. Zoneamento ambiental como subsídio para o planejamento de uso e ocupação do solo nos municípios de Corumbatai/SP. 1995. Tese (Doutorado) - Programa de Pós-Graduação em Geociências e Meio Ambiente, Instituto de Geociências e Ciências Exatas, Universidade Estadual Paulista, Rio Claro, 1995.

STEIN, D. O. Avaliação da degradação do meio físico. Bacia do Rio Santo Anastácio. Oeste Paulista. 1999. Tese (Doutorado em Geociências e Meio Ambiente). Instituto de Geociências e Ciências Exatas, Universidade Estadual Paulista, Rio Claro, 1999.

TORRES, F. T. P.; NETO, R. M.; MENEZES, S. O. Introdução à geomorfologia. São Paulo: Cengage Learning, 2012.

ZANATTA, F. A. S.; CUNHA, C. M. L.; BOIN, M. N. Análise da aplicação do atual e antigo Código Florestal na alta bacia do ribeirão Areia Dourada, Marabá Paulista (SP) (BR). Caderno Prudentino de Geografia, Presidente Prudente, n. 36, v. Especial, 2014, pp. 203-214.

ZANATTA, F. A. S.; LUPINACCI, C. M.; BOIN, M. N. O uso da terra e alterações do relevo na alta bacia do ribeirão Areia Dourada, Marabá Paulista (SP): um estudo a partir de princípios da antropogeomorfologia.
Revista Brasileira de Geomorfologia, São Paulo, v. 16, n. 1, 2015, pp.03-17. DOI: http://dx.doi.org/10.20502/ rbg.v16i1.560

Soc. \& Nat., Uberlândia, 28 (1): 21-38, jan/abr/2016 